\title{
TREASURER'S REPORT \\ NOVA SCOTIAN INSTITUTE OF SCIENCE \\ MARCH 31, 2011
}

ASSETS:

Bank Account

$5,674.44$

Investments

$63,068.14$

TOTAL ASSETS

$68,742.58$

\section{LIABILITIES AND NET WORTH:}

Accounts Payable

Science Fair

100.00

100.00

NET WORTH

$68,642.58$

TOTAL LIABILITIES AND NET WORTH

$68,742.58$

\section{INVESTMENTS:}

Renaissance High Interest Savings Account

$11,268.14$

CIBC Investment

Certificate A @ 5.05\% (due Jun 2011) 11,500.00

CIBC Investment

Certificate A @5.20\% (due Oct. 2012) 20,000.00

National Bank of Canada

Certificate A@2.900\% (due May 2013) 10,300.00

Montreal Trust Company

Certificate A@3.250\% (dueJuly15 2015)

$10,000.00$

TOTAL INVESTMENTS

$63,068.14$

\section{Finances}

The net worth of the Institute is $\$ 68,642.58$ For this year, revenue included a grant of $\$ 1000.00$ from the Nova Scotia Department of Tourism and Culture. The Institute also received \$431.54 from ACCESS copyright for publication royalties. A donation of $\$ 500.00$ was received from the Situating Science Cluster (SSC); this is being held for a future video award. 


\section{REVENUE AND EXPENDITURES}

\section{FOR 2010-2011}

\section{REVENUE}

Membership Dues

Individuals

$\$ 2,480.00$

Institutions

469.83

AGM (2010)

$1,482.00$

Donations/Grant

1535.00

Sales/Page charges

Proceedings

409.50

Other-Flora

770.00

\section{Income/Royalties}

Investment Income

$2,458.01$

Access Copyright Royalty

431.54

Bank Interest

0.91

$\$ 10,036.79$

\section{EXPENDITURES}

Advertisement/Promotion

$\$ 542.36$

AGM (2010)

$1,557.17$

Office supplies

27.49

Rent

56.50

Postage

$1,738.21$

Donations/Prizes

$1,750.00$

Honoraria

200.00

Proceedings Costs

$3,814.86$

Flora Costs

$1,897.50$

$\$ 11,584.09$

Net income: (Loss) $(\$ 1,547.30)$ 
Expenditures for donations and prizes totalled $\$ 1750.00$. This included $\$ 100.00$ donations to each of 10 regional Science Fairs in Nova Scotia, and two writing competition awards, one each of $\$ 500.00$ for graduate and $\$ 250.00$ for undergraduate.

\section{Membership}

The Institute has 106 individual members including 6 life members and 3 student members. This year there were 21 new members. Dues from individual members amounted to $\$ 2,480.00$ and from institutional members $\$ 469.83$.

Respectfully submitted to the AGM

May 2, 2011

Elaine D. McCulloch

Treasurer 